JFFI. 2019; 6(1) 315-324

www.jurnal.farmasi.umi.ac.id/index.php/fitofarmakaindonesia

\title{
PERBANDINGAN AKTIVITAS ANTIOKSIDAN JAHE EMPRIT (Zingiber officinale var Amarum) DAN JAHE MERAH (Zingiber officinale var Rubrum) DALAM SEDIAAN CAIR BERBASIS BAWANG PUTIH DAN KORELASINYA DENGAN KADAR FENOL DAN VITAMIN C
}

\author{
Ike Yulia Wiendarlina ${ }^{1}$, Runi Sukaesih ${ }^{1}$ \\ ${ }^{1}$ Program Studi Farmasi, Fakultas Matematika dan Ilmu Pengetahuan Alam, \\ Universitas Pakuan Bogor \\ *yulia21760@gmail.com
}

Submission Date: 30-09-2018; $\quad$ Review Completed: 03-11-2018; $\quad$ Accepted Date: 18-12-2018

\begin{abstract}
Garlic (Allium sativum L.), ginger emprit (Zingiber officinale var Amarum) and red ginger (Zingiber officinale var Rubrum) contain active compounds from the phenol group which have antioxidant properties. This study aims to determine the ratio of antioxidant activity of red ginger and ginger in garlic-based liquid preparations using DPPH reagent (1.1 diphenyl-2 picrylhydrazyl) and determine its correlation with total phenol and vitamin $C$ levels contained in both liquid preparations. Total phenol content was determined by reacting folin-ciocalteu and vitamin C levels were determined by titrimetric method. Total phenol levels are expressed as mg GAE (Gallic Acid Equivalent) per gram of preparation, antioxidant activity is expressed as $I C_{50}(\mu \mathrm{g} / \mathrm{mL})$, and vitamin $C$ is expressed as percent (\%). The results show that total phenol content of emprit and red ginger in garlic-based preparation were 80,296 $\mathrm{mgGAE} / \mathrm{g}$ preparations and 159,164 $\mathrm{mgGAE} / \mathrm{g}$ preparations respectively, antioxidant activity (IC 50 ) for each preparation were $3,310 \mu \mathrm{g} / \mathrm{mL}$ and $2,075 \mu \mathrm{g} / \mathrm{mL}$ respectively and the vitamin C level were $4.338 \%$ and $6.372 \%$. Correlation test showed the very strong and significant correlation existed between antioxidant activity and the total phenol levels in both emprit and red ginger-garlic preparation but no significant correlation detected between antioxidant activity and vitamin C levels of both preparations.
\end{abstract}

Keywords: garlic-based preparations, emprit ginger, red ginger, antioxidant, phenol level

\section{PENDAHULUAN}

Radikal bebas adalah suatu senyawa yang memiliki elektron tidak berpasangan pada orbital terluarnya sehingga menyebabkan senyawa tersebut sangat reaktif untuk mencari pasangannya melalui penyerangan dan pengikatan elektron yang berada di sekitarnya. Reaksi ini dalam tubuh dapat menimbulkan reaksi berantai yang mampu merusak struktur sel, jika tidak dihentikan akan menimbulkan berbagai penyakit seperti kanker, jantung, katarak, penuaan dini, serta penyakit degeneratif lainnya. Antioksidan adalah suatu senyawa yang dapat memperlambat proses oksidasi dari radikal bebas, sehingga dapat melindungi sel - sel dari kerusakan yang disebabkan oleh molekul tidak stabil yang dikenal sebagai radikal bebas. Senyawa ini bekerja dengan cara mendonorkan elektronnya kepada molekul radikal bebas atau disebut senyawa yang bersifat oksidan, yaitu dengan cara pengikatan oksigen dan pelepasan hidrogen. Proses oksidasi penting untuk metabolisme tubuh, tetapi jika molekul yang dihasilkan jumlahnya berlebihan dapat merusak kesehatan seperti merusak sel yang mengoksidasi DNA, sehingga dapat berakibat berlangsungnya mutasi gen. Berdasarkan mekanisme kerjanya antioksidan diklasifikasikan menjadi 3 tipe, yaitu Antioksidan Primer (Antioksidan Endogenus), Antioksidan Sekunder (Antioksidan Eksogenus) dan Antioksidan Tersier (Musarofah, 2015).

Bawang putih (Allium sativum L.) memiliki kandungan senyawa sulfida, yaitu Dialil sulfida atau dalam bentuk teroksidasi disebut dengan aliin yang mempunyai fungsi fisiologis yang sangat luas, termasuk diantaranya adalah antioksidan, antikanker, antitrombotik, antiradang, penurunan tekanan darah dan dapat menurunkan kolesterol darah (Hidayat dan 
Rodame, 2015). Umbi batang bawang putih juga mengandung saltivine yang dapat mempercepat pertumbuhan sel dan jaringan serta merangsang susunan sel saraf, Alilpropil - disulfida sebagai antelmintik (Lintas Media, 2014). Jahe emprit (Zingiber officinale var Amarum) merupakan bahan alami yang banyak mengandung komponen fenolik aktif seperti sogaol, gingerol dan gingerone yang memiliki efek antioksidan di atas Vitamin E dan sebagai antikanker (Hidayat dan Rodame, 2015). Jahe merah (Zingiber officinale var Rubrum) memiliki rasa yang sangat pedas dengan aroma yang sangat tajam dan banyak mengandung komponen fenolik aktif seperti halnya jahe emprit, tetapi memiliki kandungan minyak atsiri yang lebih tinggi dibandingkan dengan jahe emprit (1,5-3,5\% untuk jahe emprit dan 2,58-3,90\% untuk jahe merah) (Setyaningrum dan Cahyo, 2014). Jeruk lemon mengandung minyak atsiri yang di dalamnya terlarut senyawa - senyawa kimia seperti, Linalil asetat, Geranil asetat, sitral, limonene, felandren dan kumarin bioflavonoid. Jeruk lemon mengandung $8 \%$ Asam sitrat dan memiliki kandungan vitamin $\mathrm{C}$ yang tinggi dibandingkan jeruk nipis serta sebagai sumber vitamin $\mathrm{A}, \mathrm{B}_{1}, \mathrm{~B}_{2}$, fosfor, kalsium, pektin dan serat. Lemon memiliki berbagai macam penggunaan seperti, membersihkan tubuh, membantu kerja sistem pencernaan dan merangsang kerja hati (Lintas Media, 2014). Menurut Zu et.al. (2010) kandungan minyak atsiri (monoterpen dan sesquiterpen) seperti limonene memiliki aktivitas antibakteri dimana pada buah jeruk lemon juga memiliki kandungan minyak atsiri berupa limonene. Menurut Noghata et.al. (2006), tanaman jeruk mengandung komponen flavonoid yang memiliki aktivitas antibakteri. Madu ( $\mathrm{Mel}$ depuratum) mengadung asam organik, asam amino, vitamin A, B kompleks, C, D, E, dan K, mineral dan enzim. Selain sebagai sumber nutrisi, energi, vitamin, dan mineral madu juga berperan aktif sebagai antioksidan (Nurheti, 2014). Cuka apel adalah suatu zat yang dibuat dari senyawa-senyawa yang berada dalam buah apel melalui proses fermentasi menggunakan microorganisme (Saccharomyses cerevisiae dan Zymomonas mobilis) sebagai biokatalis untuk mengubah bahan baku menjadi produk (Riadi, 2007). Cuka apel mengandung nutrisi yang sama seperti pada buah apel yaitu pektin, betakarotin, kalium, serat, termasuk enzim dan asam amino yang terbentuk selama proses fermentasi. Fitokimia di dalam apel seperti tanin dan flavonoid dapat berfungsi sebagai antioksidan yang melawan kolesterol jahat (Low Density Lipoprotein/LDL) yang potensial menyumbat pembuluh darah. Antioksidan ini dapat mencegah kerusakan sel-sel atau jaringan pembuluh darah. Pada saat bersamaan, antioksidan akan meningkatkan kolesterol baik (High Density
Lipoprotein/HDL) yang bermanfaat untuk mencegah penyakit jantung, pembuluh darah dan stroke (Lintas Media, 2014).

Antioksidan diperlukan untuk meredam aktivitas radikal bebas, dikenal sebagai senyawa yang dapat mendonorkan elektronnya (pemberi atom hidrogen) kepada radikal bebas, sehingga menghentikan reaksi berantai dan mengubah radikal bebas menjadi bentuk yang stabil (Hamid, et.al., 2010). Musarofah (2015) menyatakan bahwa target utama radikal bebas adalah protein, asam lemak tak jenuh, liporotein dan unsur DNA termasuk karbohidrat. Reaksi berantai pada pembentukan radikal bebas melalui tiga tahap, yaitu:

1. Tahap inisiasi, yaitu awal pembentukan radikal bebas.

Persamaan Reaksi $\quad: \mathrm{RH} \rightarrow \mathrm{R}^{*}+\mathrm{H}^{*}$

2. Tahap propagasi adalah perpanjangan rantai radikal.

Persamaan Reaksi $\quad: \mathrm{R}^{*}+\mathrm{O}_{2} \rightarrow \mathrm{ROO} * \mathrm{ROO} *+$ $\mathrm{RH} \rightarrow \mathrm{ROOH}+\mathrm{R}^{*}$

3. Tahap terminasi ialah bereaksinya senyawa radikal dengan radikal lain atau dengan penangkap radikal, sehingga potensi propagasinya rendah.

Persamaan Reaksi : $\mathrm{R}^{*}+\mathrm{R}^{*} \rightarrow \mathrm{R}-\mathrm{R}$

$\mathrm{ROO}^{*}+\mathrm{R}^{*} \rightarrow \mathrm{ROOR}$

$\mathrm{ROO}^{*}+\mathrm{ROO}^{*} \rightarrow \mathrm{ROOR}+\mathrm{O}_{2}$

Mekanisme kerja antioksidan memiliki dua fungsi, yakni fungsi utama sebagai pemberi atom hidrogen (antioksidan primer) yang dapat memberikan atom hidrogen secara cepat ke radikal lipida ( $\left.\mathrm{R}^{*}, \mathrm{ROO}^{*}\right)$ atau mengubahnya ke bentuk yang stabil. Fungsi kedua yaitu memperlambat laju autooksidasi dengan berbagai mekanisme di luar mekanisme pemutusan rantai autooksidasi dengan pengubahan radikal lipida ke bentuk yang lebih stabil (Musarofah, 2015). Potensi antioksidan dinyatakan dengan nilai konsentrasi hambat $50 \%\left(\mathrm{IC}_{50}\right)$. Semakin kecil $\mathrm{IC}_{50}$ menunjukkan semakin tinggi aktivitas antioksidan suatu senyawa atau zat.

Tabel 1. Tingkat Kekuatan Antioksidan

\begin{tabular}{cc}
\hline Intensitas & IC $_{\mathbf{5 0}}$ \\
\hline Sangat Aktif & $<50$ \\
Aktif & $50-100$ \\
Sedang & $101-250$ \\
Lemah & $251-500$ \\
Tidak Aktif & $>500$ \\
\hline
\end{tabular}

(Sumber: Sandhiutami, dkk., 2014)

Metode yang sering digunakan untuk menentukan aktivitas antioksidan pada umumnya yaitu metode DPPH (1,1 - Difenil - 2 - Pikrilhidrazil). DPPH merupakan suatu radikal bebas yang stabil dan tidak membentuk dimer akibat delokalisasi dari elektron bebas pada seluruh molekul (Molyneux, 2004). Antolovich, et.al. (2001) menyatakan bahwa 
intensitas warna dari hasil uji diinterpretasikan sebagai $\mathrm{IC}_{50}$, yaitu jumlah antioksidan yang diperlukan untuk menurunkan konsentrasi awal DPPH sebesar $50 \%$. Pada metode ini tidak diperlukan substrat sehingga memiliki keuntungan, yaitu lebih sederhana dan waktu analisis yang lebih cepat, namun untuk hasil optimum diperlukan ketelitian yang baik. Apak, et.al. (2007) menyebutkan metode DPPH memiliki kelemahan yaitu kurang sensitif untuk mengukur aktivitas antioksidan selain dari senyawa fenol.

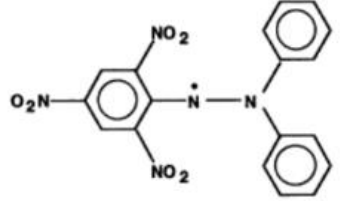

1: Diphenylpicrylhydrazyl (free radical)



2: Diphenylpicrylhydrazine (nonradical)
Gambar 1. Struktur Kimia Senyawa 1,1-Diphenyl2-Picrylhydrazyl (DPPH) Sebelum dan Sesudah Reaksi Penghambatan Radikal Bebas (Sumber:

Molyneux, 2004)

Titrasi iodometri langsung melibatkan larutan kanji sebagai indikator karena warna biru gelap dari kompleks iodin - kanji bertindak sebagai suatu tes yang amat sensitif untuk iodin. Mekanisme pembentukan kompleks yang berwarna ini dinyatakan sebagai molekul - molekul iodin yang bertahan di permukaan $\beta$ - amylose, yaitu suatu konstituen dari kanji (Day \& Underwood, 2002).

Tabel 2. Penentuan - penentuan melalui Titrasi Iodometri Langsung

\begin{tabular}{cl}
\hline Analit & \multicolumn{2}{c}{ Reaksi } \\
\hline Antimon (III) & $\mathrm{HSbOC}_{4} \mathrm{H}_{6} \mathrm{O}_{6}+\mathrm{I}_{2}+\mathrm{H}_{2} \mathrm{O} \rightleftarrows \mathrm{HSbO}_{2} \mathrm{C}_{4} \mathrm{H}_{4} \mathrm{O}_{6}+2 \mathrm{H}^{+}+2 \mathrm{I}^{-}$ \\
Arsenik (III) & $\mathrm{HAsO}_{2}+\mathrm{I}_{2}+2 \mathrm{H}_{2} \mathrm{O} \rightleftarrows \mathrm{H}_{3} \mathrm{AsO}_{4}+2 \mathrm{H}^{+}+2 \mathrm{I}^{-}$ \\
Ferosianida & $2 \mathrm{Fe}(\mathrm{CN})^{4}{ }_{6}+\mathrm{I}_{2} \rightleftarrows 2 \mathrm{Fe}(\mathrm{CN})^{3-}{ }_{6}+2 \mathrm{I}^{-}$ \\
Hidrogen sianida & $\mathrm{HCN}+\mathrm{I}_{2} \rightleftarrows \mathrm{ICN}+\mathrm{H}^{+}+\mathrm{I}^{-}$ \\
Hidrazin & $\mathrm{N}_{2} \mathrm{H}_{4}+2 \mathrm{I}_{2} \rightleftarrows \mathrm{N}_{2}+4 \mathrm{H}^{+}+4 \mathrm{I}^{-}$ \\
Belerang (sulfida) & $\mathrm{H}_{2} \mathrm{~S}+\mathrm{I}_{2} \rightleftarrows 2 \mathrm{H}^{+}+2 \mathrm{I}^{-}+\mathrm{S}$ \\
Belerang (sulfida) & $\mathrm{H}_{2} \mathrm{SO}_{3}+\mathrm{I}_{2}+\mathrm{H}_{2} \mathrm{O} \rightleftarrows \mathrm{H}_{2} \mathrm{SO}_{4}+2 \mathrm{H}^{+}+2 \mathrm{I}^{-}$ \\
Tiosulfat & $2 \mathrm{~S}_{2} \mathrm{O}^{2-}{ }_{3}+\mathrm{I}_{2} \rightleftarrows \mathrm{S}_{4} \mathrm{O}^{2-}{ }_{6}+2 \mathrm{I}^{-}$ \\
Timah (II) & $\mathrm{Sn}^{2+}+\mathrm{I}_{2} \rightleftarrows \mathrm{Sn}^{4+}+2 \mathrm{I}^{-}$ \\
\hline
\end{tabular}

(Sumber : Day \& Underwood, 2002)

Hanani (2015) menyatakan bahwa senyawa fenol memiliki inti aromatik sehingga memiliki serapan di daerah sinar UV, dan apabila ditambah dengan larutan basa akan terjadi pergeseran batokrom. Umumnya senyawa fenol memiliki absorbansi pada daerah sinar UV di bawah $300 \mathrm{~nm}$.
Tabel 3. Spektrum Kelompok Senyawa Fenol Sederhana dan Asam Fenolat

\begin{tabular}{clcc}
\hline \multirow{2}{*}{ No. } & \multicolumn{1}{c}{ Senyawa } & Etanol & Etanol + NaOH \\
\cline { 3 - 4 } & & $\lambda$ Maksimum (nm) & $\lambda$ Maksimum (nm) \\
\hline A. & \multicolumn{3}{c}{ Fenol sederhana } \\
\hline 1. & Resorsinol & 276,283 & 293 \\
2. & 2-Metilresorsinol & 275,280 & 288 \\
3. & 4-Metilresorsinol & 282 & 291 \\
4. & Katekol & 279 & penguraian \\
5. & Hidrokuinon & 295 & penguraian \\
6. & Pirogalol & 266 & penguraian \\
7. & Floroglusinol & 269,273 & 350 \\
\hline B. & & Asam fenolat \\
\hline 1. & Asam salisilat & 235,305 & 225,297 \\
2. & Asam vanilat & 260,290 & 285,297 \\
3. & Asam siringat & 271 & 298 \\
4. & Asam gentisat & 237,335 & 308 \\
5. & Protokatekoat & 260,295 & 240,283 \\
\hline
\end{tabular}

(Sumber : Hanani, 2015)

Beberapa penelitian telah dilakukan untuk melihat hubungan antara kandungan fenol dengan aktivitas antioksidan. Hasil penelitian yang dilakukan oleh Arif, dkk. (2014) menunjukkan aktivitas antioksidan penangkapan radikal DPPH memiliki hubungan dengan kandungan fenolik dan flavonoid tanaman. Penelitian yang dilakukan oleh Ratnayani, dkk. (2012) menunjukkan hasil total senyawa fenolat pada madu randu dan madu kelengkeng dapat dilihat bahwa adanya hubungan yang linear dengan aktivitas antiradikal bebasnya. Hasil penelitian Kusumowati dan Sudjono (2012) menunjukkan hasil bahwa aktivitas antiradikal ekstrak daun sirih, daun jati belanda dan daun katuk memiliki korelasi positif dengan kadar fenolik totalnya, dimana semakin tinggi kadar fenolik mengakibatkan semakin besar aktivitas antiradikalnya.

Akar penelitian ini dimaksudkan untuk menentukan kadar fenol total, vitamin $\mathrm{C}$ dan aktivitas antioksidan sediaan cair berbasis bawang putih dengan menggunakan metode DPPH serta korelasinya dengan menggunakan SPSS 25.

\section{METODE PENELITIAN}

\section{A. Alat}

Alat yang akan digunakan dalam penelitian ini antara lain, alat-alat perebusan, alat-alat gelas, alumunium foil, blender, cawan uap, kapas, kertas saring, lampu spiritus, saringan teh, sentrifugator, spectrofotometer UV-VIS, stopwatch, termomether, timbangan.

\section{B. Bahan}

Bahan - bahan yang digunakan dalam penelitian ini meliputi: bawang putih tunggal (Allium sativum L.), cuka apel, jahe emprit (Zingiber 
officinale var Amarum), jahe merah(Zingiber officinale var Rubrum), jeruk lemon (Citrus limon [L.] Osbeck.), dan madu (Mel depuratum),1,1difenil-2-pikrilhidrazil (DPPH), akuades, amonia, arsen trioksida asam asetat encer, asam klorida $1 \mathrm{~N}$, asam klorida $2 \mathrm{~N}$, asam klorida $5 \mathrm{~N}$, asam klorida pekat, asam galat, diklorometan, etanol $70 \%$, etanol $80 \%$, eter, besi (III) klorida $1 \%$, besi (III) klorida 3 $\%$, folin - ciocalteau, gelatin $1 \%$, gelatin $10 \%$, indikator kanji, indicator jingga metil, iodium serbuk, kalium iodide, metanol $50 \%$, methanol $80 \%$, natrium borohidrida, natrium hidroksida $1 \mathrm{~N}$, natrium hidrokarbonat, natrium karbonat $15 \%$, natrium klorida $10 \%, \mathrm{pH}$ Universal, Pereaksi Benedict, Pereaksi Libermann - Burchard, timbal - asetat $25 \%$, Pereaksi Mayer, Pereaksi Bouchardat, Pereaksi Dragendorff, serbuk Magnesium (Mg), serbuk seng (Zn).

\section{Prosedur Kerja}

Penelitian ini diawali dengan preparasi sampel, pengolahan bahan, penentuan bobot jenis sediaan cair berbasis bawang putih, uji fitokimia, uji aktivitas antioksidan menggunakan metode DPPH, analisis kuantitatif fenol total dan vitamin C.

1. Preparasi Sampel

Bahan yang digunakan dalam penelitian ini adalah Bawang putih tunggal (Allium sativum L.), cuka apel, jahe emprit (Zingiber officinale var Amarum), jahe merah (Zingiber officinale var Rubrum), jeruk lemon (Citrus limon [L.] Osbeck.), dan madu (Mel depuratum) yang diperoleh dari pasar tradisional dan toko herbal di daerah Kota Bogor.

Bahan - bahan yang telah dikumpulkan diolah sesuai formula yang digunakan secara empiris sebagai antioksidan oleh masyarakat dengan beberapa modifikasi.

Tabel 4. Formula Ramuan Tradisional (Empiris)

\begin{tabular}{cc}
\hline $\begin{array}{c}\text { Bahan yang } \\
\text { diperlukan }\end{array}$ & Formula \\
\hline $\begin{array}{c}\text { Bawang putih } \\
\text { tunggal }\end{array}$ & $250 \mathrm{~g}$ \\
Jahe & $250 \mathrm{~g}$ \\
Lemon & $50 \mathrm{~mL}$ \\
Cuka apel & $125 \mathrm{~mL}$ \\
Madu & $150 \mathrm{~mL}$ \\
Air & $\pm 1 \mathrm{~L}$ \\
\hline
\end{tabular}

2. Penentuan Bobot Jenis Sediaan Cair berbasis Bawang Putih

Menurut Martin, et al., (1993), cara penentuan bobot jenis suatu bahan dengan menggunakanalat piknometer yaitu:

a. Piknometer dan tutupnya dibersihkan dengan akuades dan dibilas dengan alkohol $70 \%$. Kemudian dikeringkan dalam oven pada suhu $100^{\circ} \mathrm{C}$ selama 60 menit, lalu didinginkan pada suhu kamar.

b. Setelah itu, piknometer dan tutupnya ditimbang bobotnya dalam keadaan kosong pada timbangan analitik, hasilnya dicatat. Penimbangan dilakukan secara triplo.

c . Selanjutnya sampel (sediaan cair berbasis bawang putih) dimasukkan ke dalam piknometer secara penuh sesuai volume piknometer yang digunakan kemudian ditutup dan dibersihkan dengan kain bersih/tisu.

d. Setelah itu, piknometer dan tutupnya yang telah berisi sampel ditimbang bobotnya pada timbangan analitik, hasilnya dicatat. Penimbangan dilakukan secara triplo.

e. Dihitung bobot jenis sampel dengan persamaan berikut ini :

$=\frac{\left(\sum \text { Bobot piknometer }+ \text { tutup }+ \text { sampel }\right)-\left(\sum \text { Bobot piknometer kosong }\right)}{}$

$\rho$

Volume piknometer

3. Uji Fitokimia Bahan

a. Uji Alkaloida

Sampel ditimbang sebanyak \pm 1 g dikocok dengan $20 \mathrm{~mL}$ metanol dan $3 \mathrm{~mL}$ amonia, kemudian dipanaskan di atas penangas air pada suhu $60{ }^{\circ} \mathrm{C}$ sambil dikocok selama 15 menit, selanjutnya didinginkan dan disaring. Filtrat yang diperoleh dipekatkan hingga lebih kurang $3 \mathrm{~mL}$, kemudian ditambah $5 \mathrm{~mL}$ asam klorida $1 \mathrm{~N}$ dan digunakan untuk percobaan berikut:

1. Filtrat dipipet $1 \mathrm{~mL}$ dan disimpan di atas kaca arloji, lalu ditambahkan 2 tetes pereaksi Mayer. Hasil positif ditunjukkan dengan terbentuknya endapan berwarna putih.

2. Filtrat dipipet $1 \mathrm{~mL}$ dan disimpan di atas kaca arloji, lalu ditambahkan 2 tetes pereaksi Bouchardat. Hasil positif ditunjukkan dengan terbentuknya endapan berwarna cokelat sampai hitam.

3. Filtrat dipipet $1 \mathrm{~mL}$ dan disimpan di atas kaca arloji, lalu ditambahkan 2 tetes pereaksi Dragendorff. Hasil positif ditunjukkan dengan terbentuknya endapan berwarna jingga cokelat.

Uji Alkaloid bernilai positif jika sekurang kurangnya dua dari percobaan di atas menunjukkan hasil yang positif (Hanani, 2015).

b. Uji Flavonoid

Menurut Hanani (2015), uji flavonoid dapat dilakukan dengan beberapa macam pereaksi

flavonoid berikut ini:

1. Sampel sebanyak $\pm 2 \mathrm{~g}$ ditimbang dengan seksama dikocok dengan $30 \mathrm{~mL}$ diklormetan selama 15 menit, kemudian disaring. Filtrat diuapkan hingga kering dan residu dilarutkan 
dalam 1 - $2 \mathrm{~mL}$ metanol $50 \%$, jika perlu dilakukan dengan pemanasan di atas penangas air. Filtrat ditambah sedikit serbuk magnesium $(\mathrm{Mg})$ dan 5 - 6 tetes asam klorida $5 \mathrm{M}$, lalu dipanaskan sebentar di atas penangas air. Hasil positif ditunjukkan dengan terbentuknya warna merah hingga merah lembayung yang menandakan adanya senyawa flavanon, flavonol, flavanonol dan dihidroflavonol. Uji ini disebut Uji Shinoda.

2. Filtrat dibuat sama pada point a, kemudian ditambah sedikit serbuk seng ( $\mathrm{Zn})$ dan 5 - 6 tetes asam klorida $5 \mathrm{M}$, lalu dipanaskan sebentar di atas penangas air. Hasil positif ditunjukkan dengan terbentuknya warna merah hingga merah lembayung yang menandakan adanya senyawa flavanonol dan dihidroflavonol, sedangkan senyawa flavanon dan flavonoid tidak berwarna atau merah muda lemah.

3. Larutan uji sebanyak $1 \mathrm{~mL}$ ditambah dengan larutan besi (III) klorida sama banyak. Warna hijau biru yang timbul disebabkan oleh flavonoid yang memiliki gugus hidroksil bebas pada cincin A atau B.

4. Larutan uji diuapkan dan dilarutkan dalam metanol $1 \mathrm{~mL}$, kemudian ditambahkan $10 \mathrm{mg}$ natrium borohidrida dan 2 tetes asam klorida $2 \mathrm{~N}$. Setelah 1 menit, larutan uji ditambah beberapa tetes asam klorida pekat. Warna lembayung yang timbul menunjukkan adanya senyawa flavonon.

c. Uji Polifenol

Sampel sejumlah \pm 2 g ditimbang dengan seksama dan dimasukkan ke dalam erlenmeyer ditambah $10 \mathrm{~mL} \mathrm{HCl} 2 \mathrm{M}$, dipanaskan di atas penangas air selama 30 menit. Setelah disaring, kemudian filtrat dimasukkan ke dalam corong pisah. Ampas disaring lagi dengan metoda dan pelarut yang sama. Filtrat dicampur, ditambah dengan $20 \mathrm{~mL}$ eter, dikocok dan dibiarkan kedua larutan terpisah. Larutan eter dipisahkan, diuapkan hingga sisa sekitar $5 \mathrm{~mL}$. Larutan uji sebanyak $1 \mathrm{~mL}$ ditambah pereaksi folin - ciocalteu, dipanaskan sebentar di atas penangas air. Larutan mengandung senyawa polifenol jika terbentuk warna biru (Hanani, 2015).

d. Uji Saponin

Hanani (2015) menyatakan bahwa uji saponin dapat dilakukan sebagai berikut:

a. Sampel ditimbang sebanyak $\pm 1 \mathrm{~g}$ direfluks dengan $20 \mathrm{~mL}$ etanol $70 \%$ di atas penangas air selama 10 menit, lalu disaring dan diuapkan hingga kental. Filtrat $1 \mathrm{~mL}$ ditambah pereaksi LB (Libermann - Burchard, berupa campuran asam asetat anhidrida dengan asam sulfat pekat). Warna hijau hingga biru menunjukkan adanya senyawa saponin. b. Uji Busa, dilakukan dengan cara sampel ditimbang sebanyak $\pm 1 \mathrm{~g}$ dicampur dengan akuades sebanyak $10 \mathrm{~mL}$ dan dipanaskan di atas penangas air selama 10 menit. Setelah dingin, larutan dikocok kuat - kuat selama 10 detik sehingga akan terbentuk buih yang stabil (selama tidak kurang dari 10 menit). Uji saponin menunjukkan hasil positif jika buih tidak hilang dengan penambahan 1 tetes asam klorida $2 \mathrm{~N}$.

e. Uji Tanin

Hanani (2015) menyatakan, sampel ditimbang sebanyak $\pm 2 \mathrm{~g}$ diekstraksi dengan etanol $80 \%(30 \mathrm{~mL})$, menggunakan pendingin tegak selama 15 menit, kemudian disaring. Filtrat yang diperoleh diuapkan di atas penangas air. Pada sisa penguapan ditambahkan akuades panas, lalu diaduk. Setelah dingin, larutan disentrifugasi. Cairan di atasnya dipisahkan dengan cara dekantasi, dan larutan digunakan sebagai larutan uji. Terhadap larutan uji dilakukan percobaan sebagai berikut :

a. Ditambah larutan $10 \%$ gelatin, akan timbul endapan warna putih.

b. Ditambah $\mathrm{NaCl}$ - gelatin (larutan $1 \%$ gelatin dalam larutan $10 \% \mathrm{NaCl}$ dengan perbandingan 1:1). Timbul endapan dan dibandingkan dengan hasil pada butir a.

c. Ditambah larutan $3 \%$ besi (III) klorida, terjadi warna hijau biru hingga kehitaman.

d. pH larutan uji dibuat sekitar 3 - 6, jika perlu ditambahkan $\mathrm{NaHCO}_{3}$ atau asam asetat encer.

Larutan tersebut kemudian ditambahkan beberapa tetes larutan timbal (II) asetat $25 \%$ atau larutan Striknin nitrat sehingga dihasilkan endapan.

4. Uji Aktivitas Antioksidan Metode DPPH (1,1Difenil-2-Pikrilhidrazil) (Molyneux, 2004)

Ditimbang seksama setara $100 \mathrm{mg}$ sampel sediaan berbasis bawang putih dimasukkan ke dalam labu ukur $100 \mathrm{~mL}$, kemudian dilarutkan dengan metanol sampai tanda batas (1000 ppm). Dipipet 1 $\mathrm{mL}$ larutan sampel sediaan berbasis bawang putih 1000 ppm, kemudian dimasukkan ke dalam labu ukur $10 \mathrm{~mL}$ dan dilarutkan dengan metanol sampai tanda batas $(100 \mathrm{ppm})$. Larutan uji dibuat deret $1 \mathrm{ppm}, 2$ ppm, 3 ppm, 4 ppm, 5 ppm dan 6 ppm dengan cara diambil masing-masing $0,1 \mathrm{~mL} ; 0,2 \mathrm{~mL} ; 0,3 \mathrm{~mL} ; 0,4$ $\mathrm{mL} ; 0,5 \mathrm{~mL} ; 0,6 \mathrm{~mL}$ dan dimasukkan ke dalam labu ukur $10 \mathrm{~mL}$, kemudian diencerkan dengan metanol sampai tanda batas. Ditambahkan $1 \mathrm{ml}$ larutan DPPH $1 \mathrm{mM}$ lalu dihomogenkan. Larutan uji didiamkan selama waktu optimum pada suhu kamar. Diukur absorbannya pada panjang gelombang maksimum (sebelumnya labu ukur sudah dilapisi alumunium foil). Persamaan regresi yang diperoleh dari data konsentrasi dengan absorban sehingga didapat nilai koefisien korelasi (r). 
5. Analisis Kuantitatif Kadar Fenol Total (Hanani, 2015)

Sampel setara $2 \mathrm{~g}$ ditimbang dengan seksama dan dimasukkan ke dalam erlenmeyer ditambah $10 \mathrm{~mL} \mathrm{HCl} 2 \mathrm{M}$, dipanaskan di atas penangas air selama 30 menit. Setelah disaring, kemudian filtrat dimasukkan ke dalam corong pisah. Filtrat ditambah dengan $20 \mathrm{~mL}$ eter, dikocok dan dibiarkan kedua larutan terpisah. Larutan eter dipisahkan, diuapkan hingga sisa sekitar $5 \mathrm{~mL}$ dan dilarutkan dalam akuades hingga tanda batas labu 10 $\mathrm{mL}$. Kemudian larutan uji dipipet sebanyak $1 \mathrm{~mL}$ dan dimasukkan dalam labu takar $10 \mathrm{~mL}$, ditambah dengan $500 \mu \mathrm{L}$ pereaksi folin-ciocalteau dan $2 \mathrm{~mL}$ natrium karbonat $\left(\mathrm{Na}_{2} \mathrm{CO}_{3}\right) 15 \% \mathrm{~b} / \mathrm{v}$, dicampurkan secara perlahan. Selanjutnya ditambahkan akuades hingga tanda batas. Larutan dipindahkan ke dalam tabung reaksi dan ditutup dengan alumunium foil, dipanaskan di atas penangas air pada suhu $50{ }^{\circ} \mathrm{C}$ selama 5 menit. Didinginkan dan diinkubasi pada waktu inkubasi optimum, absorban diukur pada panjang gelombang maksimum $\left(\lambda_{\max }\right)$. Hasil pengukuran ini dinyatakan sebagai berat setara dengan asam galat tiap berat sediaan berbasis bawang putih.

6. Analisis Kuantitatif Kadar Vitamin C (Filbert, et.al., 2014)

Ditimbang 10 gram sediaan berbasis bawang putih lalu dimasukan dalam labu takar 50 $\mathrm{mL}$, ditambahkan akuades hingga tanda batas. Disaring dengan corong menggunakan kertas saring untuk memisahkan filtratnya. Kemudian diambil 5 $\mathrm{mL}$ filtrat dengan menggunakan pipet volume, dimasukan ke dalam erlenmeyer, ditambahkan 2 tetes larutan amilum dan $20 \mathrm{~mL}$ akuades. Sampel dititrasi dengan larutan iodium $0,1 \mathrm{~N}$ dengan menggunakan indikator kanji hingga terjadi perubahan warna menjadi biru pekat. Kemudian dihitung kadarnya dengan menggunakan persamaan berikut ini:

$$
\text { Kadar Vitamin } C=\frac{\mathrm{VI}_{2} \times \mathrm{NI}_{2} \times 8,806}{m g \text { sampel } \times 0,1} \times 100 \%
$$

Dimana $1 \mathrm{~mL}$ iodium $0,1 \mathrm{~N}$ setara dengan $8,806 \mathrm{mg} \mathrm{C}_{6} \mathrm{H}_{8} \mathrm{O}_{6}$ (Depkes. Republik Indonesia, 1979).

\section{HASIL DAN PEMBAHASAN Karakteristik Sediaan Cair Berbasis Bawang Putih}

Sediaan cair berbasis bawang putih dibuat berdasarkan formula empiris dengan berbagai modifikasi agar diperoleh hasil sediaan yang baik. Sediaan cair ini memiliki aroma dan rasa khas kuat yang berasal dari bawang putih tunggal, sediaan cair yang mengandung jahe emprit memiliki warna coklat muda sedangkan yang mengandung jahe merah memiliki warna sediaan coklat kemerah - merahan.

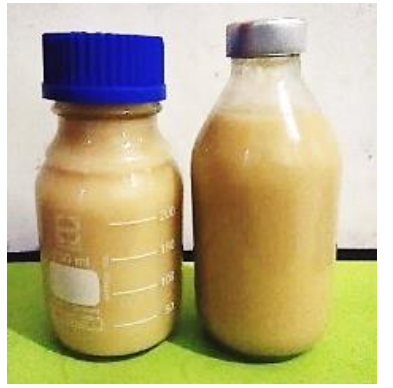

Gambar 2. Sediaan Cair Berbasis Bawang Putih Sediaan cair berbasis bawang putih selanjutnya dilakukan penentuan bobot jenis untuk mengetahui kemurnian sediaan dan uji fitokimia untuk mengetahui senyawa yang terkandung dalam sampel sediaan berbasis bawang putih sehingga dapat dilakukan uji aktivitas antioksidan serta analisis kadar fenol total dan vitamin $\mathrm{C}$ dalam sediaan cair berbasis bawang putih. Pada penelitian ini penentuan bobot jenis menggunakan piknometer $25 \mathrm{~mL}$ sebagai alat ukur dan diperoleh hasil bobot jenis sebesar $1,000532 \mathrm{~g} / \mathrm{mL}$ untuk sediaan dengan komposisi jahe emprit dan $1,000315 \mathrm{~g} / \mathrm{mL}$ untuk jahe merah. Hasil ini menunjukkan bahwa kedua sediaan cair berbasis bawang putih memiliki bobot jenis yang lebih tinggi dibandingkan dengan air $(\mathrm{bj}$ air $=1 \mathrm{~g} / \mathrm{mL})$.

\section{Hasil Uji Fitokimia Sediaan Cair Berbasis Bawang Putih}

Uji fitokimia dilakukan untuk mengetahui golongan senyawa yang terkandung dalam suatu tanaman atau sediaan. Berdasarkan hasil uji fitokimia diketahui kedua sediaan cair berbasis bawang putih mengandung sejumlah senyawa, yaitu alkaloid, fenolik, flavonoid, dan glikosida.

Tabel 5. Hasil Uji Fitokimia Sediaan Cair Berbasis Bawang Putih

\begin{tabular}{|c|c|c|c|c|c|}
\hline \multirow{2}{*}{ Sampel } & \multicolumn{5}{|c|}{ Parameter Uji } \\
\hline & Alkaloid & Flavonoid & Polifenol & Saponin & Tanin \\
\hline Sediaan Cair & \multirow[b]{2}{*}{+} & \multirow[b]{2}{*}{+} & \multirow[b]{2}{*}{+} & \multirow[b]{2}{*}{ - } & \multirow[b]{2}{*}{ - } \\
\hline $\begin{array}{c}\text { Berbasis } \\
\text { Bawang Putih } \\
\text { (Jahe Emprit) }\end{array}$ & & & & & \\
\hline Sediaan Cair & \multirow[b]{2}{*}{+} & \multirow[b]{2}{*}{+} & \multirow[b]{2}{*}{+} & \multirow[b]{2}{*}{ - } & \multirow[b]{2}{*}{ - } \\
\hline $\begin{array}{c}\text { Berbasis } \\
\text { Bawang Putih } \\
\text { (Jahe Merah) }\end{array}$ & & & & & \\
\hline
\end{tabular}

Keterangan: $(+)=$ Positif mengandung golongan senyawa 


\section{Hasil Pengujian Aktivitas Antioksidan Metode DPPH}

Metode radikal 1,1-Difenil-2-Pikrilhidrazil ( $\alpha, \alpha$-Difenil- $\beta$-Pikrilhidrazil) (DPPH) merupakan suatu metode yang telah digunakan secara luas untuk mengetahui aktivitas antioksidan dengan mekanisme kerja uji bioaktivitas penangkapan radikal bebas. Aktivitas radikal bebas ini yaitu dengan cara mendelokasi elektron bebas pada suatu molekul dan menyebabkan molekul tersebut tidak reaktif sebagaimana radikal bebas yang lain. Suatu senyawa dapat dikatakan memiliki aktivitas antioksidan apabila senyawa tersebut mampu mendonorkan atom hidrogennya untuk berikatan dengan DPPH membentuk DPPH tereduksi yang ditandai dengan semakin hilangnya warna ungu (Molyneux, 2004). Penentuan aktivitas antioksidan dinyatakan dalam $\mathrm{IC}_{50}(\mu \mathrm{g} / \mathrm{mL})$ sebagai kapasitas antioksidan. Hasil penentuan aktivitas antioksidan pada sediaan cair berbasis bawang putih dibandingkan dengan standar asam galat dengan menggunakan metode DPPH ditunjukkan dalam Tabel 6 .

Tabel 6. Aktivitas Antioksidan Metode DPPH

\begin{tabular}{lc}
\hline \multicolumn{1}{c}{ Sampel } & $\begin{array}{c}\text { Aktivitas Antioksidan } \\
\left(\mathbf{I C}_{\mathbf{5 0}}(\boldsymbol{\mu \mathbf { g }} \mathbf{\mathbf { m L }})\right)\end{array}$ \\
\hline Sediaan Cair & 3,310 \\
Berbasis Bawang & \\
Putih & \\
(Jahe Emprit) & \\
Sediaan Cair & \\
Berbasis Bawang & 2,075 \\
Putih & \\
(Jahe Merah) & \\
Standar Asam & \\
Galat & 1,878 \\
\hline
\end{tabular}

Berdasarkan data tersebut diketahui perbandingan nilai aktivitas antioksidan antara standar asam galat dan kedua sediaan cair berbasis bawang putih, dimana kedua sediaan cair berbasis bawang putih memiliki nilai IC $_{50}$ yang lebih besar daripada standar asam galat. Sedangkan di antara kedua sediaan cair berbasis bawang putih, kandungan jahe merah memiliki nilai $\mathrm{IC}_{50}$ yang lebih baik dibandingkan dengan sediaan dengan kandungan jahe emprit. Meskipun demikian aktivitas antioksidan kedua sediaan cair berbasis bawang putih termasuk ke dalam taraf yang sangat baik, hal ini disebabkan dari $\mathrm{IC}_{50}$ yang nilainya $<50$. Perbedaan signifikan nilai aktivitas ini dikarenakan asam galat memiliki kandungan senyawa fenol asam organik yang sifatnya murni. Di samping itu, Apak, et.al. (2007) menyebutkan DPPH kurang sensitif untuk mengukur aktivitas antioksidan selain dari senyawa fenol, sehingga kapasitas antioksidan metode DPPH ini akan memberikan nilai positif untuk uji aktifitas senyawa fenol.

\section{Hasil Pengujian Kadar Fenol Total}

Senyawa fenol diketahui memiliki aktivitas antioksidan. Senyawa fenol merupakan metabolit sekunder yang memainkan peranan dalam pemeliharaan tubuh manusia. Adanya kandungan kimia pada tumbuhan seperti fenol, flavonoid dan tannin mengindikasikan kemungkinan adanya aktivitas antioksidan yang mampu membantu mencegah terjadinya penyakit melalui aktivitas penangkalan radikal bebas (Meenaksi, et.al., 2012).

Pengujian kandungan senyawa fenol merupakan dasar dilakukannya pengujian aktivitas antioksidan, karena diketahui bahwa senyawa fenolat berperan dalam mencegah terjadinya peristiwa oksidasi. Kadar fenol total sediaan berbasis bawang putih pada penelitian ini ditentukan dengan menggunakan prinsip follin-ciocalteu yang didasarkan pada reaksi oksidasi reduksi dimana terbentuknya senyawa kompleks berwarna biru. Pereaksi ini mengoksidasi fenolat (garam alkali) atau gugus fenolik - hidroksi mereduksi asam heteropoli (fosofomolibdat - fosfotungstat) yang terdapat dalam pereaksi follin-ciocalteu menjadi suatu kompleks molibdenum - tungsten. Senyawa fenolik bereaksi dengan reagen follin - ciocalteu hanya dalam suasana basa agar terjadi disosiasi proton pada senyawa fenolik menjadi ion fenolat. Agar tercipta kondisi basa digunakan $\mathrm{Na}_{2} \mathrm{CO}_{3} 15 \%$ b/v. Semakin besar konsentrasi senyawa fenolik maka semakin banyak ion fenolat yang mereduksi asam heteropoli (fosofomolibdat - fosfotungstat) menjadi kompleks molibdenum - tungsten sehingga warna biru yang dihasilkan semakin pekat (Apsari dan Susanti, 2011). Penentuan kadar fenol total sediaan cair berbasis bawang putih dihitung berdasarkan nilai absorbansi yang diperoleh dari masing - masing deret yang telah dibuat berdasarkan jumlah sampel uji yang diambil. Nilai absorbansi yang diperoleh kemudian dimasukkan ke dalam persamaan regresi linear standar asam galat sebagai nilai (y) untuk memperoleh nilai konsentrasi fenolik (x). Kadar fenol total dinyatakan sebagai mgGAE/g sediaan cair berbasis bawang putih. Kadar fenol total yang dihasilkan oleh sediaan cair berbasis bawang putih dengan ulangan sebanyak tiga kali dapat dilihat pada Tabel 7. Dimana tinggi rendahnya kandungan fenol total menunjukkan aktivitas antioksidan dalam sediaan cair berbasis bawang putih tersebut. 
Tabel 7. Kadar Fenol Total Sediaan Cair Berbasis Bawang Putih

\begin{tabular}{ccc}
\hline Sampel Uji & $\begin{array}{c}\text { Kadar Fenol Total } \\
\text { (mg GAE/g sediaan) }\end{array}$ & $\begin{array}{c}\text { Kadar Fenol Total } \\
\text { (mg GAE/g sediaan) }\end{array}$ \\
\hline Sediaan Cair & 82,889 & \\
Berbasis & 79,556 & 80,296 \\
Bawang Putih & 78,444 & \\
(Jahe Emprit) & & 159,164 \\
\hline Sediaan Cair & 160,193 & \\
Berbasis & 157,352 & \\
Bawang Putih & 159,948 & \\
(Jahe Merah) & & \\
\hline
\end{tabular}

\section{Hasil Pengujian Kadar Vitamin C}

Sebelum dilakukan penetapan kadar vitamin C sampel kedua sediaan cair berbasis bawang putih dilakukan uji kualitatif terlebih dahulu untuk mengetahui ada atau tidaknya kandungan vitamin $\mathrm{C}$ di dalam sediaan cair berbasis bawang putih. Uji kualitatif pada penelitian ini menggunakan pereaksi Benedict. Setelah dipanaskan di atas lampu spiritus selama kurang lebih 1 menit, sediaan cair berbasis bawang putih menunjukkan adanya endapan berwarna hijau kekuningan seperti yang terlihat pada Gambar 3. Hal ini membuktikan bahwa sediaan cair berbasis bawang putih memiliki kandungan vitamin C.

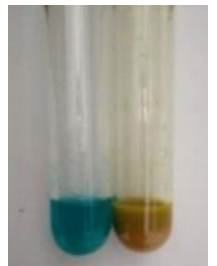

(A)

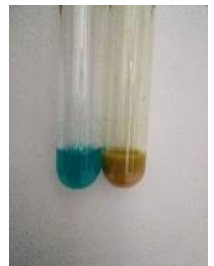

(B)
Gambar 3. Hasil Uji Kualitatif Vitamin C Sediaan Cair Berbasis Bawang Putih (A) Jahe Merah (B) Jahe Emprit

Berdasarkan hasil uji kualiatif yang ditunjukkan oleh Gambar 3 diketahui adanya perubahan warna sebelum dan setelah pemanasan terhadap kedua sediaan cair berbasis bawang putih. Sebelum diberi perlakuan kedua sediaan berbasis bawang putih yang direaksikan dengan pereaksi Benedict berwarna biru, sedangkan setelah diberi perlakuan campuran larutan berubah menjadi warna hijau kekuningan dengan membentuk endapan. Pereaksi Benedict akan bereaksi dengan gugus aldehid, kecuali aldehid dalam gugus aromatik dan alpha hidroksi keton. Sehingga dapat disimpulkan bahwa kedua sediaan cair berbasis bawang putih benar mengandung senyawa vitamin $\mathrm{C}$.
Hasil penetapan kadar vitamin $\mathrm{C}$ yang terkandung dalam kedua sediaan berbasis bawang putih adalah 6,372 \% untuk jahe merah dan 4,338 \% untuk jahe emprit. Rauf (2015) menyatakan bahwa komponen utama kanji yaitu amilosa dan amilopektin. Dimana amilosa memiliki rantai lurus dan memberikan warna biru jika bereaksi dengan iodium. Sedangkan amilopektin memiliki rantai bercabang dan memberikan warna merah violet saat bereaksi dengan iodium. Secara kimia, amilopektin memiliki lebih banyak gugus hidroksil yang reaktif dibandingkan dengan amilosa. Gugus hidroksil merupakan penentu sifat hidrofilik dari suatu molekul, sehingga amiloektin memiliki kelarutan dalam air yang lebih tinggi dibandingkan dengan amilosa. Mekanisme reaksi indikator kanji adalah sebagai berikut:

Amilum $+\mathrm{I}_{2} \rightarrow$ Iod-Amilum (biru)

Iod-Amilum (biru) $+\mathrm{Na}_{2} \mathrm{~S}_{2} \mathrm{O}_{3} \rightarrow 2 \mathrm{NaI}+\mathrm{Na}_{2} \mathrm{~S}_{4} \mathrm{O}_{6}+$ amilum (tak berwarna)

Vitamin C mengalami oksidasi dengan melepas dua atom hidrogen menjadi asam dehidroaskorbat untuk menstabilkan komponen radikal seperti terlihat pada reaksi di bawah ini:
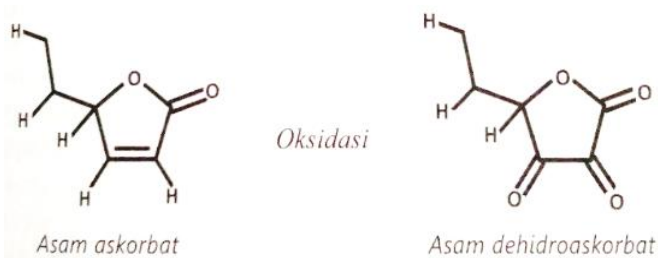

(Sumber: Rauf, 2015)

Gambar 4. Oksidasi Asam askorbat menjadi Asam dehidroaskorbat

Iodin merupakan agensia pengoksidasi lemah, sehingga vitamin $\mathrm{C}\left(\mathrm{C}_{6} \mathrm{H}_{8} \mathrm{O}_{6}\right)$ segera teroksidasi menjadi asam dehidroaskorbat $\left(\mathrm{C}_{6} \mathrm{H}_{6} \mathrm{O}_{6}\right)$. Sedangkan iodin tereduksi menjadi iodida. Kelebihan iodium yang bereaksi dengan indikator kanji menyebabkan terbentuknya kompleks warna biru.

\section{Hasil Analisis Data}

Data dianalisis menggunakan uji asosiasi yaitu uji korelasi. Uji korelasi digunakan untuk mengetahui hubungan antara dua variabel dengan signifikan. Pada penelitian ini data yang tersaji dalam bentuk interval atau rasio yang mempunyai beberapa varian sehingga menggunakan uji korelasi bivariate sebagai metode uji yang terdapat pada analisis data SPSS 25. Hasil uji korelasi antara kadar fenol total dan vitamin $\mathrm{C}$ dengan aktivitas antioksidan ditunjukkan pada Tabel 8 . 
Tabel 8. Uji Korelasi Kadar Fenol Total dan Vitamin C dengan Aktivitas Antioksidan

\begin{tabular}{llrrr}
\hline \multicolumn{4}{c}{ Correlations } \\
\hline & $\begin{array}{c}\text { Aktivitas } \\
\text { Antioksidan }\end{array}$ & $\begin{array}{c}\text { Vitamin } \\
\text { C }\end{array}$ & $\begin{array}{c}\text { Kadar } \\
\text { Fenol Total }\end{array}$ \\
\hline \multirow{2}{*}{ Aktivitas } & Pearson Correlation & 1 & .968 & $.999^{*}$ \\
Antioksidan & Sig. (2-tailed) & & .161 & .023 \\
& $N$ & 3 & 3 & 3 \\
& Pearson Correlation & .968 & 1 & .977 \\
Vitamin C & Sig. (2-tailed) & .161 & & .138 \\
& $N$ & 3 & 3 & 3 \\
Kadar & Pearson Correlation & $.999^{*}$ & .977 & 1 \\
Fenol Total & Sig. (2-tailed) & .023 & .138 & 3 \\
\cline { 2 - 5 } & $N$ & 3 & 3 & \\
\hline *. Correlation is significant at the 0.05 level (2-tailed). & \\
\hline
\end{tabular}

Berdasarkan data pada Tabel 8 diperoleh nilai pearson correlation pada masing - masing variabel dimana nilai ini menunjukkan nilai $r$ (korelasi). Hasil uji korelasi aktivitas antioksidan dengan kadar fenol total yaitu 0,999 pada probabilitas $0.05 \%$ yang menunjukkan bahwa korelasi antar variabel tersebut memiliki korelasi yang sangat kuat $(0,91$ - 0,99). Pada output korelasi diketahui nilai probabilitas kadar fenol total terhadap aktivitas antioksidan lebih kecil dari probabilitasnya $(0,023<$ 0,025), maka dapat disimpulkam bahwa varibel tersebut berkorelasi secara signifikan dimana aktivitas antioksidan dapat disebabkan oleh kandungan total fenol dari kedua sediaan cair berbasis bawang putih. Sedangkan untuk kadar vitamin $\mathrm{C}$ terhadap aktivitas antioksidan memiliki nilai pearson correlation 0,968 dengan nilai signifikan 0,161 pada probabilitas $0,05 \%(0,025)$ menunjukkan adanya hubungan korelasi yang sangat kuat $(0,91-0,99)$. Akan tetapi karena nilai signifikan lebih besar daripada probabilitas $0,05 \%(0,025)$, maka hasil ini menunjukkan korelasi antara kadar vitamin $\mathrm{C}$ dengan aktivitas antioksidan tidak signifikan.

\section{KESIMPULAN}

a. Hasil uji kadar fenol total sediaan cair berbasis bawang putih yaitu sebesar 80,296 mgGAE/g sediaan untuk jahe emprit dan 159,164 mgGAE/g sediaan untuk jahe merah. Hasil uji kadar vitamin $\mathrm{C}$ sediaan cair berbasis bawang putih nilai rata - rata pada 3 kali ulangan yaitu sebesar 4,338 $\%$ pada jahe emprit dan $6,372 \%$ pada jahe merah. Nilai rata - rata aktivitas antioksidan $\left(\mathrm{IC}_{50}\right)$ dari sediaan berbasis bawang putih dengan menggunakan metode DPPH adalah $3,310 \mu \mathrm{g} / \mathrm{mL}$ untuk jahe emprit dan $2,075 \mu \mathrm{g} / \mathrm{mL}$ untuk jahe merah.

b. Terdapat korelasi yang sangat kuat dan signifikan antara kadar fenol total sediaan berbasis bawang putih dengan aktivitas antioksidan (metode DPPH) dengan nilai koefisien korelasi $\left(\mathrm{r}^{2}\right)$ 0,999*. Hanya menunjukkan adanya korelasi yang sangat kuat tetapi tidak signifikan antara kadar vitamin $\mathrm{C}$ kedua sediaan cair berbasis bawang putih dengan aktivitas antioksidan (metode DPPH) dengan nilai koefisien korelasi $\left(r^{2}\right) 0,968$.

\section{DAFTAR PUSTAKA}

Antolovich, M., P.D. Prenzler, E. Patsalides, S. McDonald and K. Robards .2001. Methods for Testing Antioxidant Activity. Jurnal The Royal Society of Chemistry 127 : 183 - 198.

Apak, R., Guclu, K., Demirata B., Ozyurek, M., Celik, S.E., Bektasoglu, B., Berker, K.I., and Birsen, D. 2007. Comparative Evaluation of Various Total Antioxidant Capacity Assay Applied to Phenolic Coumpounds with The CUPRAC Assay. Molecules 12 : 1496 1547.

Apsari, P.D. dan Susanti, H.2011.Perbandingan Kadar Fenolik Total Ekstrak Metanol Kelopak Merah dan Ungu Bungan Rosella (Hibiscus sabdariffa, Linn.) secara Spektrofotometri. ISBN 978-979-18458-47.

Arif, D.Y., C. Jose dan H.Y. Teruna .2014. Total Fenolik, Flavonoid serta Aktivitas Antioksidan Ekstrak n-heksan, Diklorometan dan Metanol Amarantus spinosus L. EM5 - Bawang Putih. JOM FMIPA. Vol. 1 (2) : 359 - 369.

Depkes.RI.1979. Farmakope Indonesia. Edisi III. Jakarta : Direktorat Jendral Pengawasan Obat Dan Makanan. Departemen Kesehatan Republik Indonesia.

Filbert, et.al.2014. Penentuan Aktivitas Antioksidan Berdasarkan Nilai IC $_{50}$ Ekstrak Metanol dan Fraksi Hasil Partisinya pada Kulit Biji Pinang Yaki (Areca vestiaria Giseke). Jurnal MIPA UNSRAT Online. Vol. 3 (2) : 149-154.

Hamid, A.A., O.O. Aiyelaagbe, L.A. Usman, O.M. Ameen and A. Lawal .2010. Antioxidants: Its Medicinal and Pharmacological Applications. African Journal of Pure and Applied Chemistry. Vol. 4(8), pp. 142151ISSN 1996 - 0840.

Hanani .2015. Analisis Fitokimia. Jakarta : EGC. ISBN 978-979-044-606-9.

Harmita .2006. Analisis Fitokimia. Jakarta : Cipta Kreasi Bersama, hal 15-20. ISBN 97996846-9-2. 
Hidayat, S. dan Rodame M.N. 2015. Kitab Tumbuhan Obat. Jakarta: AgriFlo (Penebar Swadaya Grup), hal 51.

Hidayat, S. dan Rodame M.N. 2015. Kitab Tumbuhan Obat. Jakarta: AgriFlo (Penebar Swadaya Grup), hal 147-148.

Kusumowati, I.T.D. dan Sudjono, T.A .2012. Korelasi Kandungan Fenolik dan Aktivitas Antiradikal Ekstrak Etanol Daun Empat Tanaman Indonesia (Piper betle, Sauropus androgynus, Averrhoa bilimbi dan Guazuma ulmifolia). Pharmacon.Vol.13 (1) : 1 - 5.

Martin, A., S. James dan C. Arthur .1993. Farmasi Fisika : Dasar - dasar Kimia Fisik dalam Ilmu Farmaseutik. Edisi Ketiga, (Diterjemahkan oleh Yoshita). Depok: Universitas Indonesia Press. ISBN: 979456-117-7.

Meenakshi, S., Umayaparvath, S., Arumugam, M., and Balasubramanian, T.2012. In vitro antioxidant properties and FTIR analysis of two seeweeds of Gulf of Mannar. Asian Pacific Journal of Tropical Biomedicine. Vol. 2 : 66 - 70 .

Molyneux, P .2004. The Use of The Stable Free Radical Diphenylpicrylhydrazyl (DPPH) for Estimating Antioxidant Activity. Songklanakarin J. Sci. Technol. 26 (2): 211 - 219

Musarofah .2015. Tumbuhan Antioksidan. Bandung : Remaja Rosdakarya. ISBN 978-979-692588-9.

Nurheti, Y .2014. Khasiat Madu untuk Kesehatan dan Kecantikan. Jakarta : ANDI. ISBN 978-97929-4688-8.

Ratnayani, K., A.A.I.A.M. Laksmiwati dan N.P.I. Septian P .2012. Kadar Total Senyawa Fenolat pada Madu Randu dan Madu Kelengkeng serta Uji Aktivitas Antiradikal Bebas dengan Metode DPPH (Difenil Pikrilhidrazil). Jurnal Kimia. Vol. 6 (2) : 163 - 168.

Rauf, Rusdin.2015.Kimia Pangan. Yogyakarta : Andi Offset. ISBN: 978-979-29-5203-2

Riadi, L. 2007.Teknologi Fermentasi. Yogyakarta : Graha Ilmu. ISBN: 978-979-756-233-5

Sandhiutami, N.M.D., L. Rahayu, T. Oktaviani dan Lili Y.S.2014. Uji aktivitas Antioksidan Rebusan Daun Sambang Getih (Hemigraphis bicolor Boerl.) dan Sambang Solok (Aerva sanguinolenta (L.) Blume) Secara In Vitro. Jakarta : Universitas Pancasila.

Setyanigrum, Hesti Dwi dan Cahyo Saparinto. 2014. Jahe. Jakarta: Penebar Swadaya, hal 13 - 25.
Tim Lintas Media. 2014. Jombang : Lintas Media. Zu, Y., H.Yu, L.Liang, Y.Fu, T.Efferth, X.Li, N.Wu. (2010). Activities Of Ten Essential Oil Towards Propionibacterium acnes And PC3, A-549 And MCF-7 Cancer Cells, Molecules 15. ISSN 1420-3049. 